\title{
Performance of lettuce under influence of different soil covers and planting spacing
}

\section{Eduardo Pradi Vendruscolo ${ }^{1}$, Luiz Fernandes Cardoso Campos ${ }^{2}$, Aliny Heloísa Alcântara Rodrigues $^{2}$, Sávio Rosa Correia ${ }^{2}$, Paulo Ricardo Oliveira ${ }^{2}$, Murillo Ribeiro Freitas ${ }^{1}$, Alexsander Seleguini ${ }^{3}$}

\author{
${ }^{1}$ Universidade Estadual de Mato Grosso do Sul, Unidade Universitária de Cassilândia, Cassilândia, Mato Grosso do Sul, Brasil. E- \\ mail: agrovendruscolo@gmail.com, mrfagro@outlook.com \\ ${ }^{2}$ Universidade Federal de Goiás, Escola de Agronomia, Goiânia, Goiás, Brasil. E-mail: luizfernandes.agronomo@gmail.com, \\ aliny_heloisa@hotmail.com, saviorosa2013@gmail.com, pauloagronomy @gmail.com \\ ${ }^{3}$ Universidade Federal do Triângulo Mineiro, Campus Universitário de Iturama, Iturama, Minas Gerais, Brasil. E-mail: \\ aseleguini@gmail.com
}

Received: 31/01/2021; Accepted: 23/04/2021.

\begin{abstract}
Lettuce cultivation is an activity of great economic importance; therefore, the use of techniques for better use of space and better-growing conditions should be evaluated. The objective of this study was to evaluate the development and yield of garden lettuce grown under different soil coverings and plant spacing. The study was conducted in an experimental area located at the School of Agronomy of the Federal University of Goiás, in the city of Goiânia, Goiás. The experiment was conducted in a randomized block design with subdivided plots in four replications. The plots consisted of three soil coverings (soil without cover, straw, and plastic cover) and the subplots in three planting spacing (PS1 $=25 \times 20 ;$ PS2 $=25 \times 25 ;$ PS3 $=25 \times 30 \mathrm{~cm}$ ), totaling nine treatments. The evaluations occurred when the plants presented their complete development, being evaluated: plant diameter, fresh head mass, stem mass, number of leaves, stem height; stem diameter; relative chlorophyll index; yield; and utilization, corresponding to the percentage of fresh marketable mass. It was found that the use of soil cover can favor the densification of lettuce cultivation. For cultivation on soil without cover or with the use of plastic as a cover, the cultivation spacing must be greater.
\end{abstract}

Keywords: Lactuca sativa L., population density, soil protection, plant morphology .

\section{Interação entre cobertura do solo e densidade de plantio sobre o cultivo de alface}

\section{RESUMO}

O cultivo de alface é uma atividade de grande importância econômica, portando, o uso de técnicas para melhor aproveitamento do espaço e melhores condições de cultivo, devem ser avaliadas. Objetivou-se com este estudo avaliar o desenvolvimento e a produtividade de plantas de alface crespa cultivadas sobre diferentes coberturas do solo e es paçamentos entre plantas. O estudo foi conduzido emárea experimental localizada na Escola de Agronomia da Universidade Federal de Goiás, na cidade de Goiânia, Goiás. O experimento foi conduzido em delineamento experimental de parcelas subdivididas, com quatro repetições. Os tratamentos consistiram em três coberturas do solo (solo descoberto, palhada e cobertura plástica) e três espaçamentos de plantio (PS1 = 25 x 20; PS2 = 25 x 25; PS3 = $25 \times 30 \mathrm{~cm}$ ), perfazendo nove tratamentos. Foi utilizada mudas de alface crespa, cultivar 'Vanda'. Foram avaliadas as características: diâmetro da planta; massa fresca de cabeça; massa do caule; número de folhas; altura do caule; diâmetro do caule; índice relativo de clorofila; produtividade; e aproveitamento, correspondente ao percentual de massa fresca comercializável. Verificou-se que o adensamento do cultivo de alface, pode ser favorecido pelo uso de cobertura do solo. Para cultivo em solo descoberto ou comuso de plástico, como cobertura, o espaçamento de cultivo deve ser maior.

Palavras-chave: Lactuca sativa L., densidade populacional, proteção do solo, morfologia vegetal. 


\section{Introduction}

Lettuce (Lactuca sativa L.) is the most widely cultivated leafy vegetable in periurban areas and the green belts of cities, intensively, standing out as one of the most economically important vegetables in Brazil, among the leafy ones (Brzezinski et al., 2017). Vegetable producers, in general, explore small areas; therefore, management changes that allow an increase in income and yield without reducing the finalquality of the product are essential in this agricultural activity (Vidigal et al., 2020).

Currently, several vegetable planting techniques have been studied, such as the use of mulching, or soil cover, which consists of using different materials in order to establish better cultivation conditions, in addition to acting to increase the characteristics of vegetable yield and quality (Blind and Silva Filho, 2015). The coverings can vary, using organic vegetable materials or plastic films, which converge in terms of beneficial effects, favoring the species of commercial interest by suppressing the development of weeds, protecting against injuries to leaves and fruits, anticipating the harvest, and better phytos anitary control (Meneses et al., 2016; Castoldi et al., 2006), maintaining soil temperature, and decreasing evaporation, allowing for a better soil moisture condition (Meneses et al., 2016; Kosterna, 2014).

In addition to the benefits observed, when using organic vegetable materials, such as soil cover, one can also see a number of advantages, such as the improvement in physical properties (aggregation of particles and reduction of soil compaction), chemical (increase in soil organic matter content in the decomposition and mineralization of plant residues) and biological (increased activity of microorganisms) in the soil (Costa et al., 2015). Also, different vegetation cover types can result in different economic returns, depending on their qualitative and quantitative characteristics (Vendruscolo et al., 2017). According to Farias et al. (2017), lettuce plants grown under plastic soil cover showed better results when compared to plants grown in soil without cover.

This improvement can be related to the maintenance of adequate levels of water in the soil, together with the smaller oscillation of daily soil temperature and increased capacity for nutrient absorption, due to the favor of root activity (Meneses et al., 2016; Kosterna, 2014), in addition to acting in the reduction of weeds that may reduce crop yield due to competition for water, light and essential nutrients for the growth and development of the crop of economic interest (Souza et al., 2016).
Another factor widely studied and which influences the production of lettuce is the spacing, and the greater spacing provided more significant averages of fresh and dry mass. This result can be explained due to the larger area occupied by the plant (Cecconello et al., 2020). On the other hand, planting density tends to generate smaller plants due to the existing competition for environmental resources, such as water, nutrients, and light (Vasconcelos et al., 2017), as well as to increase the number of plants per area and to enable an increase in yield and profitability (Vendruscolo et al., 2019).

The objective of this work was to evaluate the development and yield of garden lettuce plants grown under different soil coverings and cultivation spacing between plants.

\section{Material and Methods}

The study was conducted from May 1 to June 14, 2016, in an experimental area located at the School of Agronomy of the Federal University of Goiás, in the city of Goiânia-GO $\left(16^{\circ} 35^{\prime} \mathrm{S}, 49^{\circ} 16^{\prime} \mathrm{W}\right.$ and altitude of $725 \mathrm{~m})$. For the locality, the following average climatic indicators are verified: annual precipitation of 1,575 $\mathrm{mm}$, and average monthly temperature of $22.9{ }^{\circ} \mathrm{C}$, predominance of the Aw climate, characterized by a tropical climate with a rainy season between October and April and a period with rainfall below $100 \mathrm{~mm}$ monthly between May and September (Cardoso et al., 2014). The climatic records of air temperature and humidity during the conduction of the experiment were obtained in an evaporimeter station $300 \mathrm{~m}$ away from the experimental area (Figure 1)

The soil was classified as Latossolo Vermelho, containing the following chemical characteristics of the $0-0.2 \mathrm{~m}$ layer, before the experiment was implemented: $\mathrm{Ca}^{2+}: 2.8 \mathrm{cmol}_{\mathrm{c}} \mathrm{dm}^{-3}, \mathrm{Mg}^{2+}: 1.8 \mathrm{cmol}_{\mathrm{c}}$ $\mathrm{dm}^{-3}, \mathrm{~K}^{+}: 0.37 \mathrm{cmol}_{\mathrm{c}} \mathrm{dm}^{-3}, \mathrm{P}$ (Mehlich I): $25.8 \mathrm{mg} \mathrm{dm}^{-}$ ${ }^{3}$, Organic Matter: $3.0 \mathrm{~g} \mathrm{dm}^{-3}, \mathrm{Al}^{3+}: 0.0 \mathrm{cmol}_{\mathrm{c}} \mathrm{dm}^{-3}, \mathrm{H}$ + Al: $2.8 \mathrm{cmol}_{\mathrm{c}} \mathrm{dm}^{-3}$ and $\mathrm{pH}$ values $\left(\mathrm{CaCl}_{2}\right)$ : 5.3, Cation exchange capacity: $7.8 \mathrm{cmol}_{\mathrm{c}} \mathrm{dm}^{-3}$, Saturation by bases: $64,0 \%$.

Before planting, liming was carried out, aiming to increase base saturation to $80 \%$, in a dose of $1.6 \mathrm{Mg} \mathrm{ha}^{-}$ ${ }^{1}$ of limestone, incorporated with disc plow (Sousa and Lobato, 2004). The foundation fertilization consisted of the equivalent application of $320 \mathrm{~kg} \mathrm{ha}-1$ of simple superphosphate (Sousa and Lobato, 2004), with subsequent harrowing with a leveling grid and construction of the beds with a roto-enchanter. The beds were $1.00 \mathrm{~m}$ wide and were spaced $0.50 \mathrm{~m}$ apart. 


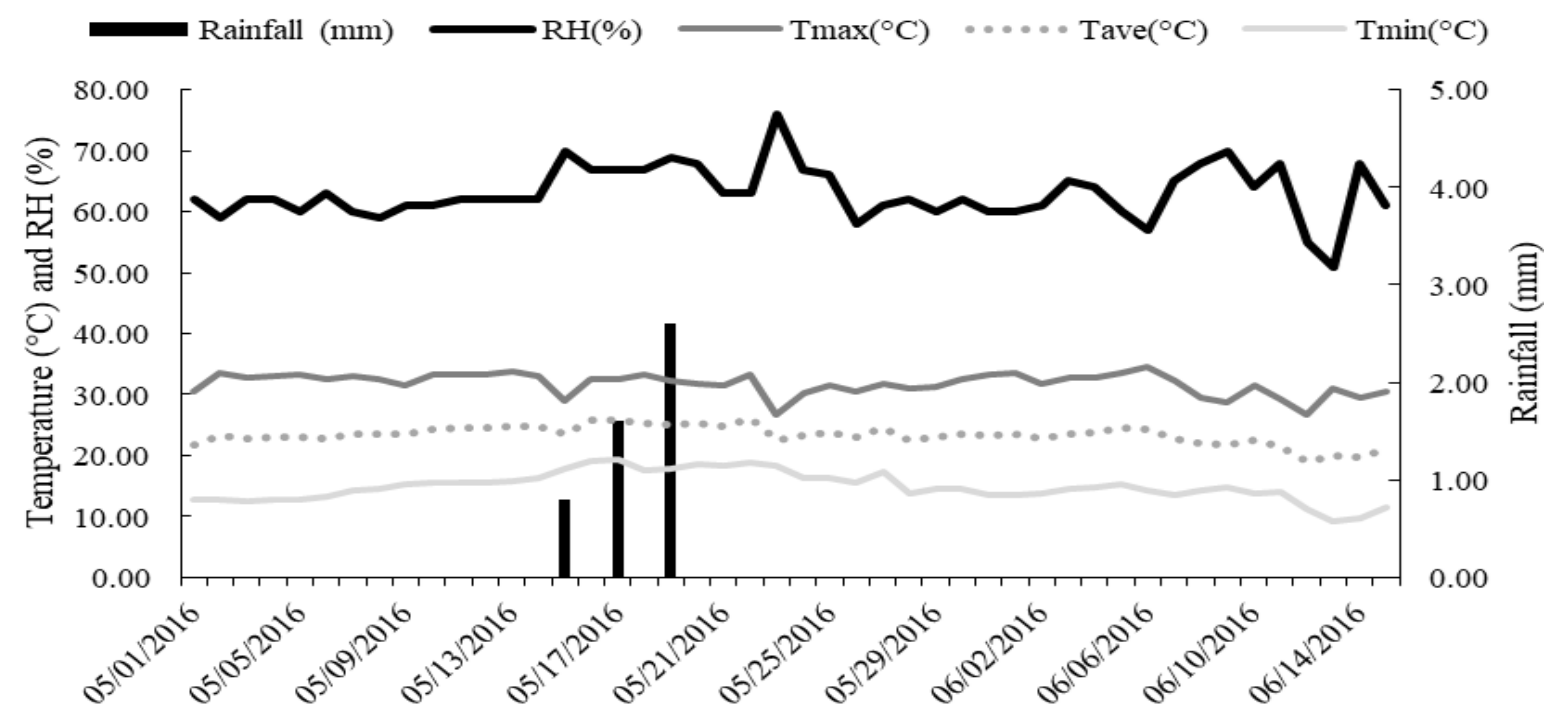

Figure 1. Relative air humidity, rainfall, and maximum, average, and minimum temperature during the study .

The experiment was carried out in a randomized block design with subdivided plots in four replications. The plots were composed by the combination of three soil coverings (soil without cover, straw, and plastic cover) and the subplots by three planting spacing (PS1= $25 \times 20 ;$ PS2 $=25 \times 25 ;$ PS3 $=25 \times 30 \mathrm{~cm}$ ), totaling nine treatments. Each sub-plot had dimensions of $1.0 \times 1.25$ $\mathrm{m}\left(1.25 \mathrm{~m}^{2}\right)$, with four planting lines, and, to obtain the sub-plot, the central plants of the two internal lines were evaluated, excluding the two outer lines and the plants at the ends of each line, used as a border.

The irrigation was carried out through drippers spaced twenty centimeters apart, in 3 polyethylene tapes suitable for this purpose, positioned between the planting lines, activated twice a day, in the morning and the afternoon. After placing the irrigation tapes, soil coverings were installed according to the treatments. For this purpose, straw from the brush cutting of potato grass (Paspalum notatum) was used and distributed over the plots until obtaining a layer about $5 \mathrm{~cm}$ thick. The plastic cover was double-sided polyethylene canvas (black and white), with the white side facing up.

The seedlings of garden lettuce, cultivar 'Vanda', were acquired in a commercial nursery, with a surplus of $10 \%$ of the quantity required for plant replacement. Seedlings were transplanted on May 1, 2016. For this purpose, pits were opened in the middle of the covers.

The cover fertilization was carried out via fertigation and divided into three applications during the cycle, at 10, 20, and 30 days after transplanting, based on the recommendations for the crop (Trani et al., 2014), applying $60 \mathrm{~kg} \mathrm{ha}^{-1}$ urea $(45 \% \mathrm{~N})$ and $50 \mathrm{~kg} \mathrm{ha}^{-1} \mathrm{KCl}$ (60\% K2O). During the lettuce cycle, there was no application of fungicides, insecticides, or herbicides. The plants were harvested 45 days after transplanting (DAT) of the seedlings when the good formation of the aerial part was observed.
The characteristics of the plant's diameter $(\mathrm{cm})$ were evaluated using a graduated ruler; fresh head mass $(\mathrm{g})$ and stem mass $(\mathrm{g})$, by weighing on a digital scale to two decimal places; the number of leaves, by counting; stem height $(\mathrm{cm})$ and stem diameter $(\mathrm{mm})$, using a digital caliper; relative chlorophyll index (RCI), measured with a digital chlorophyll meter; yield (YIELD), by multiplying the fresh mass by the population of plants obtained in each treatment; utilization (UTZN), corres ponding to the percentage of fresh mas s marketable after the removal of damaged leaves.

The data were submitted to preliminary tests of normality and homoscedasticity. As the data for all variables showed normal distribution and homogeneous variances, they were subjected to analys is of variance, and the significance of the mean squares obtained in the analysis of variance was tested by the F test at the level of $5 \%$ probability. The means relative to the treatments were compared by the LSD test at the level of $5 \%$ probability.

\section{Results and Discussion}

For the variables of plant diameter, stem height, relative chlorophyll index, and utilization, there was no interference from the treatments applied. However, it was observed that the variation factors individually affected the stem diameter and that there was an interaction between the variation factors for weight of the fresh head, number of leaves, fresh weight of the stem, and yield (Table 1).

The absence of soil cover resulted in higher mean values of fresh head mass, stem mass, and yield (Figure $2 \mathrm{~A}, \mathrm{~B}$, and $\mathrm{D}$, respectively), when the plants were grown in broader spacing and only for stem mass, no difference was observed between PS1 and PS3 spacing (Figure 2C). In general, when grown on plastic cover or straw, there was superiority of the PS3 and PS1 spacing, however, without any difference for PS1 and PS2. (Figure 2) 
Table 1. Summary of analy sis of variance of plant diameter (PD), fresh head mass (FHM), number of leaves (NL), stem height (SH), stem diameter (SD), stem mass (SM), relative chlorophyll index (RCI), y ield (YIELD) and utilization (UTZN) of lettuce plants, grown under different ground cover and spacing.

\begin{tabular}{|c|c|c|c|c|c|c|}
\hline \multirow{2}{*}{ Source of variation } & \multirow{2}{*}{ D.F. } & \multicolumn{5}{|c|}{ Mean Square } \\
\hline & & PD & FHM & $\mathrm{NL}$ & $\overline{\mathrm{SH}}$ & $\mathrm{SD}$ \\
\hline Blocks & 2 & 1.54 & 156.86 & 19.58 & 7.65 & 0.02 \\
\hline Soil covering $(\mathrm{C})$ & 2 & $13.80 \mathrm{~ns}$ & $5494.56 * *$ & $4.92 \mathrm{~ns}$ & $8.29 \mathrm{~ns}$ & $0.16^{*}$ \\
\hline Spacing $(\mathrm{S})$ & 2 & $5.17 \mathrm{~ns}$ & $238.46 \mathrm{~ns}$ & $0.83 \mathrm{~ns}$ & $8.68 \mathrm{~ns}$ & $0.09 *$ \\
\hline $\mathrm{C} \times \mathrm{S}$ & 4 & $50.85 \mathrm{~ns}$ & $5517.22 * *$ & $23.34 * *$ & $10.01 \mathrm{~ns}$ & $0.18 \mathrm{~ns}$ \\
\hline Error & 16 & 122.99 & 869.37 & 5.29 & 6.63 & 0.03 \\
\hline C.V. (\%) & & 10.55 & 15.94 & 9.96 & 52.07 & 12.62 \\
\hline Source of variation & D.F.. & SM & RCI & & YIELD & UTZN \\
\hline Blocks & 2 & 9.26 & 4.42 & & 0.06 & 1.53 \\
\hline Soil covering (C) & 2 & $33.61 *$ & $0.90 \mathrm{~ns}$ & & $2.20 * *$ & $0.23 \mathrm{~ns}$ \\
\hline Spacing (S) & 2 & $1.76 \mathrm{~ns}$ & $1.54 \mathrm{~ns}$ & & $0.10 \mathrm{~ns}$ & $0.37 \mathrm{~ns}$ \\
\hline $\mathrm{C} \times \mathrm{S}$ & 2 & $37.78 *$ & $0.94 \mathrm{~ns}$ & & $2.21 * *$ & $0.66 \mathrm{~ns}$ \\
\hline Error & 4 & 8.71 & 1.11 & & 0.35 & 0.62 \\
\hline C.V. (\%) & & 21.56 & 6.13 & & 15.94 & 0.85 \\
\hline
\end{tabular}

DF - Degrees of freedom; CV - Coefficient of variation; ns, * and ** - not significant, significant at 5\% and 1\% probability by the LSD test

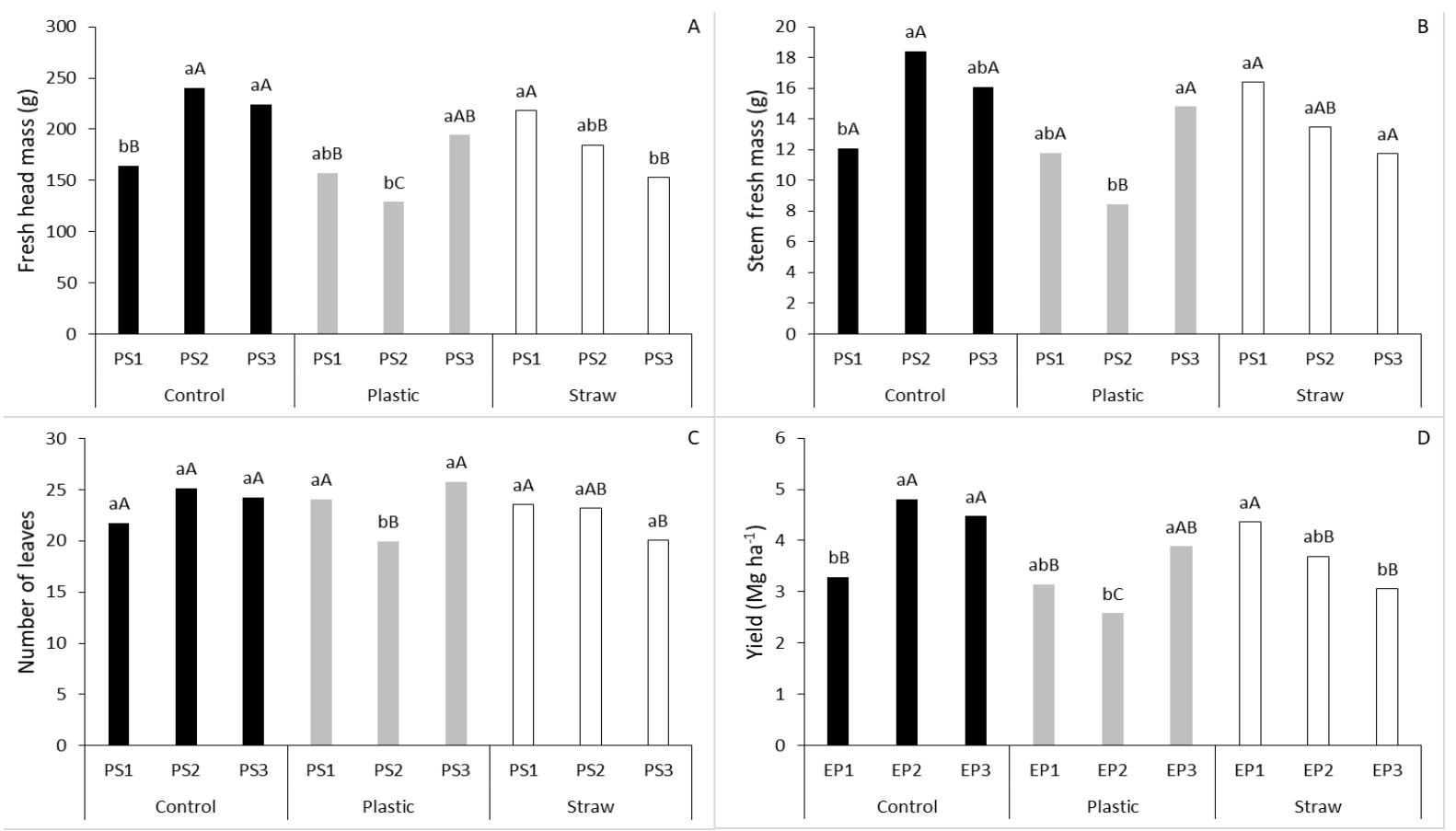

Figure 2. Average values of fresh head mass, stem fresh mass, number of leaves, and yield of lettuce plants grown under different soil coverings and planting spacing (PS1 $=25 \times 20 ;$ PS2 $=25 \times 25 ;$ PS3 $=25 \times 30 \mathrm{~cm}$ ). Averages followed by the same letter, lower case for spacing and upper case for cover, do not differ by the LSD test at $5 \%$ probability.

Among the coverings, the superiority of plants grown on straw was observed when the spacing used was PS1and inferiority of those grown on plastic cover, with PS2 spacing. In addition, when planting in PS3, there was a superiority of plants grown in soil without cover or with plastic cover, compared to those grown on straw (Figure 2). For the stem diameter, the superiority of plants grown without the presence of soil cover or when they were grown in PS3 spacing was verified, without any significant difference for those grown in PS2 (Figure 3).

The positive response of cultivation without soil cover, when using the PS2 and PS3 spacing or cultivation on the plastic cover in PS3 spacing, is related to the less competition of plants for environmental resources, mainly nutrients, due to the system being provided with daily irrigation, and, in the case of control treatment, the preventive management of weeds, before they reach the point of competing with the crop. 
This is evident due to the response observed for plants grown on straw, which, in addition to offering protection to the soil, serves as an additional source of nutrients (Kader et al., 2017a; Vendruscolo et al., 2017), enabling the obtaining of adequate results even in more dense cultivation conditions, as verified in the present study.

When evaluating the performance of beet cultivars in an organic systemunder different soil coverings, Souza et al. (2020) found that the use of vegetable remains and mulching were superior to the soil without cover, providing greater mass and yield of beet.

Straws used as soil cover, including those from grass species, together with the no-tillage system, have other positive effects in addition to those of protection and as a source of nutrients. These straws allow for an increase in the organic matter content of the soil (Loss et al., 2015). In this sense, there is also an increase in atmospheric carbon sequestration and a significant improvement in the hydrological conditions of the soil through the physical changes provided, including the increase in the levels of organic matter at greater depths in the soil profile. (Kader et al., 2017a; Kader et al., 2017b). It is also effective in suppressing weeds (Sousa et al., 2019) and can increase crop profitability (Vendruscolo et al., 2017).

The lower values observed when planting on the plastic cover are also related to the soil temperature. Due to its composition and the impossibility of exchanging heat with the environment due to the formation of a physical barrier, there is an increase in temperature under this type of material. This effect can be beneficial in crops located in temperate regions, where the increase in temperature can increase the development and yield of plants (Ibarra-Jiménez et al., 2011). However, in regions of tropical climate where the air temperature can reach values above $30^{\circ} \mathrm{C}$, the plastic cover can result in a decrease in root development and, consequently, affect the absorption of water and nutrients, essential to the functioning of the photosynthetic mechanism, and plant development (Shoaib et al., 2012; Meneses et al., 2016).

The choice of soil cover and spacing, in addition to being based on the development of plants, must take into account the availability of resources from the producer, such as labor, financial resources for the purchase of plastic cover and seedlings or seeds, or presence of plant material in the area that can be used as a cover. In this sense, Vendruscolo et al. (2019) found that, despite the lower cost for establishing a crop without soil cover, labor costs are high due to weed control, while the value of plastic cover is the factor that burdens this form of management. In that same study, the authors observed that the permanence of straw as a soil cover increases profitability due to the partial control of weeds and the low cost of implantation.

\section{Conclusions}

The use of straw as a soil cover makes it possible to increase lettuce cultivation without producing losses. When soil cover or plastic cover is not used, cultivation should be carried out in broader spacing.

\section{Authors' Contribution \\ Eduardo Pradi Vendruscolo, Luiz Fernandes Cardoso Campos, Aliny Heloís a Alcântara Rodrigues, Sávio Rosa Correia and Paulo Ricardo Oliveira participated in the planning, execution, analysis and writing stages, while Murillo Ribeiro Freitas and Alexsander Seleguini contributed to the writing of the manuscript.}

\section{Bibliographic References}

Blind, A.D., Silva Filho, D.F. 2015. Desempenho de cultivares de alface americana cultivadas com e sem mulching em período chuvoso da Amazônia. Revista Agro@ mbiente On-line, 9(2), 143-151. DOI: http://dx.doi.org/10.18227/19828470ragro.v9i2.2183

Brzezinski, C.R., Abati, J., Geller, A., Werner, F., Zucareli, C. 2017. Produção de cultivares de alface americana sob dois sistemas de cultivo. Revista Ceres, 64(1), 83-89. DOI: http://dx.doi.org/10.1590/0034-737x201764010012

Cardoso, M.R.D., Marcuzzo, F.F.N., Barros, J.R. 2014 Classificação climática de Köppen-Geiger para o estado de Goiás e o Distrito Federal. Acta geográfica, 8(16), 40-55. DOI: http://dx.doi.org/10.5654/acta.v8i16.1384

Castoldi, R., Charlo, H.C.O., Ito, L.A., Braz, L.T. 2006. Effect of plastic film mulch on the production of butterhead lettuce cultivars under protected cultivation. Acta $\begin{array}{llll}\text { Horticulturae, } & 67, & 239-242 . & \text { DOI: }\end{array}$ http://dx.doi.org/10.17660/ActaHortic.2008.767.24

Cecconello, A.M., Trogello, E., Ferro, J., Rossato, O.B. 2020. Plantio direto de alface crespa cultivada com diferentes espaçamentos. Revista Brasileira de Engenharia Agrícola e Ambiental, 24(4), 231-237. DOI: http://dx.doi.org/10.1590/1807-1929/agriambi.v24n4p231-237

Costa, N.R., Andreotti, M., Lopes, K S.M., Yokobatake, K.L., Ferreira, J.P., Pariz, C.M., Longhini, V.Z. 2015. Atributos dosolo e acúmulo de carbono na integração lavoura-pecuária em sistema plantio direto. Revista Brasileira de Ciência do Solo, 39(3), 852863. DOI: https://doi.org/10.1590/01000683rbcs20140269

Farias, D.B.S., Lucas, A.A.T., Moreira, M.A., Andrade Nascimento, L.F., Sá Filho, J.C.F. 2017. Cobertura do solo e adubação orgânica na produção de alface. Revista de Ciências $\begin{array}{llll}\text { Agrárias, } & 60(2), & 173-176 . & \text { DOI: }\end{array}$ http://dx.doi.org/10.4322/rca.2493

Ibarra-Jiménez, L., Lira-Saldivar, R. H., Valdez-Aguilar, L. A., Lozano-Del Río, J. 2011. Colored plastic mulches affect soil temperature and tuber production of potato. Acta Agriculturae Scandinavica, Section B-Soil Plant Science, 61(4), 365-371. DOI: ttps://doi.org/10.1080/09064710.2010.495724 
Kader, M.A., Senge, M., Mojid, M.A., Ito, K. 2017a. Recent advances in mulching materials and methods for modify ing soil environment. Soil and Tillage Research, 168, 155-166. DOI: https://doi.org/10.1016/j.still.2017.01.001

Kader, M.A., Senge, M.,Mojid, M.A., Nakamura, K. 2017b. Mulching type-induced soil moisture and temperature regimes and water use efficiency of soybean under rain-fed condition in central Japan. International Soil and Water Conservation Research, 5(4), 302-308. DOI: https://doi.org/10.1016/j.iswcr.2017.08.001

Kosterna, E. 2014. Soil mulching with straw in broccoli cultivation for early harvest. Journal of Ecological Engineering, 15(2), 100-107. DOI: https://doi.org/10.12911/22998993.1094985

Loss, A., Basso, A., Oliveira, B.S., Koucher, L.D.P., Oliveira, R.A.D., Kurtz, C., Lovato, P.E., Curmi, P., Brunetto, G., Comin, J.J. 2015. Carbono orgânico total e agregação do solo em sistema de plantio direto agroecológico e convencional de cebola. Revista Brasileira de Ciência do Solo, 39(4), 12121224. DOI: http://dx.doi.org/10.1590/01000683rbcs20140718

Meneses, N.B., Moreira, M.A., Souza, I.M., Bianchini, F.G. 2016. Crescimento e produtividade de alface sob diferentes tipos de cobertura do solo. Revista Agro@mbiente On-line, 10(2), 123-129. DOI: http://dx.doi.org/10.18227/19828470ragro.v10i2.3009

Shoaib, M., Ahmad, M.Z., Atif, M., Parvaiz, M., Kausar, V., Tahir, A. 2012. Review: Effect of Temperature and Water Variation on Tomato (Lycopersicon esculentum). International Journal of Water Resources and Environmental Sciences, 1(3), 82-93. DOI: 10.5829/idosi.ijwres.2012.1.3.1113

Sousa, D.M.G.; Lobato, E. (E d.) 2004. Cerrado: correção do solo e adubação. Planaltina: Embrapa Cerrados. https://www.alice.cnptia.embrapa.br/bitstream/doc/709743/1/c pafro-13328.pdf (accessed January 17, 2021).

Sousa, D.S., Saraiva, T.S., Castro, D.P. 2019. Supressão de' Plantas Daninhas em Diferentes Coberturas de Solo na Cultura de Alface. Revista Agroveterinária, Negócios e Tecnologias, $4(1), 73-83$.
Souza, A.A.L., Moreira, F.J.C., Araújo, B.D.A., Lopes, F.D.N., Silva, M.E.S., Carvalho, B.D.S. 2016. Desenvolvimento inicial de duas variedades de alface em função de dois tipos de substratos e cobertura do solo. Revista Brasileira de Engenharia de Biossistemas, 10(3), 316-326. DOI: http://dx.doi.org/10.18011/bioeng2016v10n3p316-326

Souza, L.G., Ferreira, R.L.F., Araújo Neto, S.E., Uchôa, T.L., Silva, N.M., Moura Francisco, W., Pinto, G. P. 2020. Desempenho agronômico de cultivares de beterraba sob coberturas de solo e épocas de cultivo. Scientia Naturalis, 2(2), 764-777.

Trani, P.E., Purquério, L.F.V., Figueiredo, G.J.B., Tivelli, S. W., Blat, S.F. 2014. Calagem e adubação da alface, almeirão, agrião d'água, chicória, coentro, espinafre e rúcula. IAC, Campinas. http://www.iac.sp.gov.br/imagem_informacoestecnologicas/97. pdf (accessed January 17, 2021).

Vasconcelos, U.A.A., Costa, C.C., Oliveira, M.N., Silva Barbosa, J.W., Medeiros, A.B., Sobrinho, T.G. 2017. Efeito residual do esterco ovino no cultivo da alface em diferentes espaçamentos. Revista Verde de Agroecologia e Desenvolvimento Sustentável, 12(3), 508-511.DOI: https://doi.org/10.18378/rvads.v12i3.4901

Vendruscolo, E.P., Campos, L.F.C., Arruda, E.M., Seleguini, A. 2017. Análise econômica da produção de alface crespa em cultivo sucessivo de plantas de cobertura em sistema de plantio direto. Revista Brasileira de Ciências Agrárias, 12(4), 458-463. DOI: https://doi.org/10.5039/agraria.v12i4a5478

Vendruscolo, E.P., Rodrigues, A.H.A., Correia, S.R., Oliveira, P.R., Campos, L.F.C., Seleguini, A. 2019. Economic analysis of crisp lettuce production in different planting spacing and soil cover. Advances in Horticultural Science, 33(4), 449-455. DOI: https://doi.org/10.13128/ahsc-8098

Vidigal, S.M., Carvalho Lopes, I.P., Pereira, P.R.G. 2020. Produtividade de repolho cultivado em diferentes densidades populacionais. Brazilian Journal of Development, 6(11), 86015-86027. DOI: https://doi.org/10.34117/bjdv6n11-137 